\title{
Correction: International variation in clinical practice guidelines for palliative sedation: a systematic review
}

Abarshi E, Reitjens J, Robijn L, et al. International variation in clinical practice guidelines for palliative sedation: a systematic review. BMJ Supportive \& Palliative Care 2017;3:223-9. doi:10.1136/bmjspcare-2016-001159.

The EUROIMPACT collaborator's name Miccinesi Guido has been corrected to Guido Miccinesi.

(C) Article author(s) (or their employer(s) unless otherwise stated in the text of the article) 2018. All rights reserved. No commercial use is permitted unless otherwise expressly granted.

BMJ Supportive \& Palliative Care 2018;8:239. doi:10.1136/bmjspcare-2016-001159corr1

D) Check for updates 